\title{
THE PHENOMENON OF TELETÓN IN CHILE: A LINGUISTIC PERSPECTIVE
}

\author{
El fenómeno de Teletón en Chile: Una perspectiva lingüistica \\ Anna Ivanova* \\ Tricia Mardones**
}

\begin{abstract}
Slogans, being primarily part of brand-management, present an outstanding interest for linguistic research as a vivid demonstration of how language can influence people's minds and behavior. The dramatic popularity of Teletón has attracted our attention as linguists to underpin its success by studying its textual level, i.e., the role of language in creating successful brand. For the attainment of this goal, the paper departs from a corpus analysis of Teletón slogans collected from 1978 to 2012. By studying the selected corpus, this paper intends to single out and categorize the most popular concepts raised by Teletón in its fund-raising campaigns. For a more comprehensive display and analysis, and thus discussing the way semantic prosody is realized (Sinclair, 1991; Louw, 1993; Hunston, 1997; Stubbs, 2002), this study resorted to a WordSmith@ Tool, after having turned the collected slogans into the digital format (saved as a .txt file). The obtained results evidence four main groups of linguistic strategies employed by Teletón in its campaigns: 1) inclusive language; 2) positive semantic prosody; 3) proximity to the public; 4) national lexis.

Keywords: Corpus Linguistics, slogans, Teletón, Discourse Analysis, Business Communication.

\footnotetext{
*Facultad de Educación, Universidad Autónoma de Chile. Santiago, Chile. Correo electrónico: anna.ivanova@uautonoma.cl

*Facultad de Educación, Universidad Autónoma de Chile. Santiago, Chile. Correo electrónico: tricia.mardones@uautonoma.cl

Received October, 1, 2013. Accepted March, 24, 2014.
} 


\section{RESUMEN}

Los eslóganes, son la parte principal de gestión de marca, presentan una excepcional contribución para la investigación linguística como vívida muestra de cómo el lenguaje puede influir en la mente y el comportamiento de las personas. La impresionante popularidad de Teletón ha suscitado nuestra atención como lingüistas para analizar el nivel textual que respalda su éxito, es decir, el estudio del papel lenguaje en la creación de una marca exitosa. Para la consecución de este objetivo, el artículo parte de un análisis del corpus de los eslóganes de Teletón recopilados entre 1978 a 2012. Mediante el estudio del corpus seleccionado, este trabajo se propone destacar y clasificar los conceptos más populares planteados por Teletón en sus campañas de recolección de fondos. Para un análisis más exhaustivo y, de este modo, debatir la forma en que es realizada la prosodia semántica (Sinclair, 1991; Louw, 1993; Hunston, 1997; Stubbs, 2002), el presente estudio recurrió a WordSmith@Tool, después de covertir la colección de eslóganes a un formato digital (grabado en archivo). Los resultados obtenidos evidencian cuatro grupos de estrategias lingüísticas empleadas por Teletón en sus campańas: 1) lenguaje inclusivo; 2) prosodia semántica positiva; 3) proximidad al público; 4) léxico nacional.

Palabras clave: Corpus lingüístico, eslógans, Teletón, análisis de discurso, comunicación comercial.

\section{INTRODUCTION}

In 1978 Chile celebrated the first Teletón created to raise funds for children with special abilities. Since then the country has seen 25 Teletóns, which made possible the construction of special health centres in the main cities all over Chile. On the $22^{\text {nd }}$ of January 1986, under Mario Kreutzberger's initiative, Teletón established its own private foundation, and nowadays, its board is in charge of business partnership, corporate image and advertising campaigns of Teletón.

Being held once a year, this project involves all the Chileans in their great desire to help those, who need it. During the days of Teletón, the country is converted into one big circle, where people stand together shoulder by shoulder, hoping to make their own contribution to someone out there. All this makes Chilean Teletón a real phenomenon of hope, help and progress.

In this respect, we find it rather challenging to look into this phenomenon from the scientific perspective to discover the proper formula of Teletón success. As such, we believe it is fair enough to focus our attention on language itself and investigate the phenomenon of Teletón in Chile from the linguistic perspective, as at the end, "only in and through language can one issue commands, ask questions, make offers and promises. And only through language tied into social and political institutions can one declare war, declare guilty or not guilty, prorogue parliaments, or indeed raise or lower taxes ..." (Chilton \& Schäffner, 2002: 9).

Provided that, one of the possible facets to approach this problem could be based on a multi-layered interpretative framework, drawing on discourse analysis, cognitive linguistics, and a corpus-based approach (McCarthy \& Carter, 1994). To achieve this, we propose to look into the slogans of all Teletón campaigns in search for linguistic choice in them, or, to put it in other words, the entourage, or the predominant concepts and visions 
raised by Teletón Foundation from 1978 until present days. This linguistic analysis will give us pure and undeniable empirical evidence on: 1) what kind of values are introduced through slogans, and 2) how slogans contribute to the popularity of Teletón in the country.

This approach is claimed to be innovative as, to our knowledge until now the problem of Teletón in Chile has been studied more from the socio-economical and health care perspectives (Solis et al., 2010; Garlic \& Faride, 2011; Peñuela, 2012; etc.), and no attempts have been made to employ Linguistics to approach Teletón in Chile. However, to do so, it is crucial to introduce general overviews on two main concepts as two main departing points for this paper: slogans and Corpus Linguistics.

\section{SLOGANS AS A WAY OF BUSINESS COMMUNICATION}

The origin of slogans goes back to the battlefields in ancient Scotland and Ireland, where the army officials used some simple but powerful words, phrases or sentences to encourage their soldiers for a fight. Later on these battle words were called "slogans". According to Longman Dictionary of Contemporary English (Zhou, 2004), slogan is a short phrase expressing a political or advertising message. It has to be simple, appealing and easily memorized to catch the attention of the audience. As put by Leech (1966), slogan is short, laconic phrase that a company uses over and over in its advertisement, which might be useful to reinforce the product identity.

Nowadays, in marketing sphere they stand as a way of business communication created, controlled and promoted by a company. In this respect, slogans are claimed to be the essential element of any advertising campaign as an expressive resource for the promotional messages (Zangrandi, 2007). As such, the final aim of any slogan is to capture public's attention, establish contact and convert audience into consumers (HernandoCuadrado, 1994). In other words, they are mainly used as means of propaganda ( $\mathrm{Lu}$, 1999) and of "focusing attention and exhorting to action" (Urdang \& Robbins, 1984: 17). In addition, they evoke emotional responses and perform persuasive functions. According to Robert Denton (1980), they also function to simplify complicated ideas, express group ideology and goals, create identification, provoke violent confrontations, and fulfill hopes for the future. In this sense, slogans can be considered as a particular form of public discourse aiming to unify public thoughts and agitate public actions and reactions.

Further on, being expressed through language, they stand for the linguistic code or linguistic message (Hernando-Cuadrado, 1994) used to communicate ideas to certain target markets. Therefore, linguistic concepts are useful tools in helping companies to understand how to promote their business in a more effective way. Moreover, language analysis challenges marketing and business specialists to assess carefully the language of slogans as part of business communication. In doing so, one can discover patterns of language manipulation, which in their turn, will open up wide perspectives to success in business world. These short and concise messages are then claimed to stay as semantic association between the company and its image.

All these considered we find it challenging to contribute to the modern research community of linguists and social fellows by analyzing the linguistic side of Teletón as a phenomenon in Chile. What is more, the corpus is believed to shed light on Teletón slogans, underpinning, thus, their successful employment and power for cooperation 
means. To do so, we propose to depart from the discipline of Corpus Linguistics, which main outlines are presented in the following section.

\section{CORPUS LINGUISTICS: MAIN OUTLINES}

McCarthy \& Carter (1994: 3a) define a corpus as "a large collection of written text or transcribed speech which is stored and processed by computer so as to serve as a basis for linguistic analysis and description", and Corpus Linguistics "attempts to gain linguistic knowledge through the analysis of collections of samples of naturally-occurring texts and transcribed recordings" (Wallis \& Nelson, 2001: 305). Corpus linguists are more interested in the actual language usage, its accurate description. Their study lies into functional theory of language with the objective to demonstrate how writers and speakers use language to achieve different communicative goals (Meyer, 2002).

In this respect, Wallis and Nelson (2001) proposed a 3A Perspective" on Corpus Linguistics from text to hypotheses - Annotation / Abstraction / Analysis, which can be presented in the following scheme:

\section{TEXT $\rightarrow$ ANNOTATION $\rightarrow$ CORPUS $\rightarrow$ ABSTRACTION $\rightarrow$ MODEL $\rightarrow$ ANALYSIS $\rightarrow$ HYPOTHESES}

Figure 1. 3A Perspective on Corpus Linguistics. From text to hypotheses

This scheme suggests that:

1) annotation consists of the application of a scheme to texts. Annotations may include structural markup, POS-tagging, parsing, and numerous other representations.

2) abstraction consists of the translation (mapping) of terms in the scheme to terms in a theoretically motivated model or dataset. Abstraction typically includes linguist-directed search but may include e.g., rule-learning for parsers.

3) analysis consists of statistically probing, manipulating and generalizing from the dataset. Analysis might include statistical evaluations, optimization of rule-bases or knowledge discovery methods.

The process of annotation and text analysis is quite time-consuming. It needs a lot of work and maximum concentration from a researcher. In this case a linguist prefers to use specially designed computer programs, which are able to perform the task relatively quickly and with maximum accuracy. Nowadays, there exist different kinds of software used in Corpus Linguistics for different purposes:

1) For automatic corpora annotation: CLAWS part-of speech tagger for English texts; DEXTER; WordStat; UAM Corpus Tool, Wmatrix;

2) For concordances: UAM Corpus Tool; WordSmith; A Simple Concordance Program; aConCorde (originally developed for Arabic, but now can be also used for English texts); 
3) Or lexical analysis of the corpora: WordNet - an on-line lexical reference system. The words are organized by their lexical meaning, and not by their forms; Minpair (creates a complete list of minimal pairs from a word list). If continue, the complete list will be very long, however, according to the research goals, one is free to choose the most suitable program.

Finally, it should be noted that today most corpora are POS-tagged ${ }^{1}$, but even those linguists who work with non-annotated corpus, are trying to isolate some terms from others, which are of less interest to them. In this case, basing on "3A Perspective" proposed by Wallis and Nelson (2001), annotation and abstraction are combined in doing lexical search: e.g., analysis of frequency wordlists and keyword lists of the corpus.

Thus, everything combines to believe that the paper has provided essential theoretical background to justify the selected topic for the research, i.e., slogans of Teletón in Chile. More detailed description of the instruments applied to approach this problem is presented in the following section.

\section{METHODOLOGY}

For the attainment of the above goals, this paper will resort to the close analysis of the slogans proposed by Teletón during 1978-2012. All these slogans belong to public source; therefore, they can be freely consulted by anyone interested in them on or without previous request to the authorities. Thus, the total number of slogans retrieved for this study is 24 . This selected group is claimed to be a representative collection of messages produced by Teletón for its fund-raising campaigns.

Having this in mind, the next step of our research will be to study the aforementioned corpus by drawing on a multi-layered interpretive framework (McCarthy \& Carter, 1994: 5), involving corpus linguistics, discourse analysis, and cognitive linguistics, so as to uncover the ways in which Teletón employs language for its campaigns. In this respect, corpus linguistics will contribute to general corpus design (Sinclair, 1991; Meyer, 2002; McEnery et al., 2006) as well as to its quantitative and qualitative analysis facilitated by the use of special software such as WordSmith@ (Scott, 2008). Providing that, we will employ manually-retrieval method of corpus collection due to the multi-modal nature of the selected documents. Mainly, their written archive on Teletón official webpage will require to put them all into one text format for their further analysis with WordSmith@). Having done that, the final "tailor-made" corpus (Maunter, 2009) will present a .txt document, which will be fully ready for the analysis with the chosen software.

Further on, the compiled corpus will be processed with WordSmith@; mainly, to build corpus wordlist and concordance lines. Thus, a close reading of the corpus will lead to the search of a couple of instances (Biber et al., 1998) likely to uncover a more comprehensive display and analysis of their context of occurrence, and semantic prosody (Sinclair, 1991; Stubbs, 2001; Louw \& Chateau, 2010), which "is not available to a priori intuition, but becomes visible "to the naked eye" only through corpus analysis" (Louw \& Chateau, 2010: 756). This will further allow for retrieving the context of occurrence of repeated patterns (for example, words, phrases or constructions).

\footnotetext{
${ }^{1}$ Part-of-Speech Tagging (POS tagging or POST), can be also called grammatical tagging or word-category disambiguation, is a process of marking up the words in the text according to the part of speech they belong.
} 


\section{DISCUSSION AND IMPLICATION}

The present study departs from a corpus analysis of 24 Teletón slogans from 1978 to 2012 collected from its official website. By studying the selected corpus, this paper intends to single out, categorize and analyze the linguistic features of Teletón slogans so as to discuss their role as tools to raise funds for the cooperation in Chile. For a more comprehensive display and analysis of these features and their context of occurrence, and thus discussing the way semantic prosody is realized (Sinclair, 199; Louw, 1993; Stubbs, 1995; Hunston, 2007) this study resorted to a WordSmith@ tool, after having turned the collected slogans into the digital format (saved as .txt file). Mainly, the wordlist option was used to compile the list of words according to their frequency in the corpus. Figure 2 below shows this list in the form of a word cloud, as in our opinion it gives a better visual representation of the corpus than traditional wordlists (Ivanova, 2011).

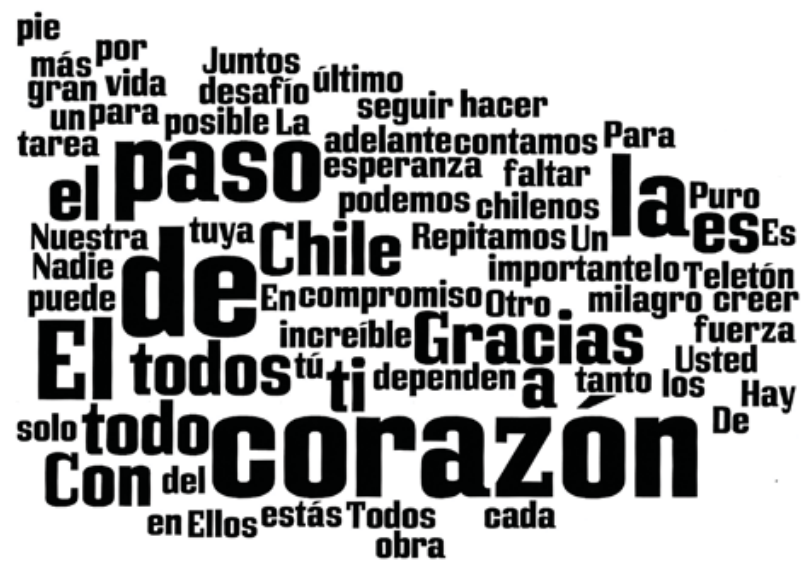

Figure 2. Word cloud of the Teletón corpus.

Taking into account that the bigger the word is in a word cloud, the more frequent it is in the corpus, one can clearly see that "corazón" $(\mathrm{N}=4)$, "paso" $(\mathrm{N}=3)$ and "todos" (and its derived forms) ( $\mathrm{N}=5)$ are the most popular words in Teletón slogans. However, if we also consider other functional words, we will see that the preposition "con" $(\mathrm{N}=2)$ and personal pronoun "tú" (and its derived forms) $(\mathrm{N}=4)$ are also frequent. At this point, tú-reference, as a "direct appeal to the audience" (Wilson, 1990: 73), enables the establishment of a direct company-audience tie. In so doing, this direct address creates an intimate bound between them (Ivanova, 2012), thus, making an illusion of Teletón direct appeal to an individual as a unique addressee of its slogan.

Further on, the close reading of "tú" (and its derived forms) concordance strings demonstrates that Teletón resorted to these pronominal forms to underline the importance of its supporters or to thank them. All these together help create an atmosphere of trust and mutual understanding between Teletón and the audience, who therefore, feel included and honored to be trusted and addressed openly. 
The same can be observed in the case of "todos" (and its derived forms), which underpins the common ground, generality and dominating inclusiveness of the public into the Teletón project.

All these help establish proximal level of communication between Teletón and the audience. Therefore, it leads to the creation of proximal and inclusive contour in Teletón slogans as a way to involve the broadest audience possible.

Having done that, we suggest a deeper analysis of the corpus by resorting to the notion of semantic prosody (Louw, 1993), which "is not available to a priori intuition, but becomes visible 'to the naked eye' only through corpus analysis" (Louw \& Chateau, 2010: 756). In so doing, and by close reading of Teletón slogans, the analysis identified the prevalence of positive "polarity preferentially associated" (Louw \& Chateau, 2010: 756) with their lexical component. In other words, according to the results, the lexical units with positive connotation such as e.g., la esperanza, posible, importante, el milagro, creer, gracias, adelante, podemos, seguir, are more frequent in the corpus, which is therefore likely to obtain favorable reception of the audience. They arouse the feelings of hope and belief, and thus, evolve a positive evaluative prosody that preferences positive perception of Teletón. Along with that, the use of the word "corazón" in Teletón slogans in 2006, 2010-1012, brings advantage to their recognition by the audience, as "corazón" symbolizes centre, love and unity.

In addition, taking into account diachronic perspective of our research, the results also reveal that slogans are not "time-sensitive" (Cataldi et al., 2010: 2), i.e., they are constant in lexis related to the same fields mentioned above.

Along with that, these units are used as a hidden tool to create optimistic impression on the future public. Similar results were obtained by Crystal (1997) in his study of twenty most frequently used adjectives in advertising slogans: new, crisp, good/ better/best, fine, free, big, fresh, great, delicious, real, full, sure, easy, bright, clean, extra, safe, special. It is necessary to underline at this point that the quantitative advantage of the semantic tags with positive connotation implicitly functions as a positive entourage of Teletón slogans. The crucial point here is that this entourage is not explicit, it is hidden behind the scene and the audience is not conscious of this trick. As such, the state (or, better put, impression) of the main topics raised in Teletón slogans is supported by the positive connotation of their lexical component. We believe it is a very important marketing strategy showing the importance to choose not just random words for the slogans, but words, which will create an atmosphere of joy and happiness for the public, especially when dealing with cooperation sphere. Thus, this can be defined then as Teletón formula of creating successful slogans, where each word matters.

In the light of these results on positive semantic connotation of words in Teletón slogans, we would like to mention one particular class of words that help create especially positive impression on the audience - patriotic lexis. In fact, it fulfills two functions: on the one hand, it sounds encouraging and optimistic; on the other, it creates inclusive effect by resorting to people's national feelings. In our corpus this type of lexis is represented by the words like Chile and los chilenos, which are believed to appeal for patriotism and national identity in order to attract more public and create a sense of eternal unity to help other people around the country. In addition, patriotic lexis together with the use of the second 
person plural forms of verbs and pronouns in slogans transmits positive unanimity, which, on the one hand, smoothes over possible differences; and on the other, arouses positive feelings such as solidarity, hospitality, ennoble work and happiness (Ortega, 2004).

Thus, the final conclusion of this study states that the corpus visualization through word cloud together with the semantic analysis of Teletón slogans clearly underpinned four main groups of linguistic strategies employed in Teletón slogans:

1) inclusive language;

2) positive semantic prosody;

3) proximity to the public;

4) national lexis.

In accordance with this, the linguistic approach to the analysis of Teletón slogans benefited the present research community by shedding light on a new perspective to investigate Teletón phenomenon in Chile, which in its turn, creates the picture of national identity and becomes a national symbol in the country.

\section{REFERENCES}

Biber, Douglas, Conrad, Susan \& Reppen, Randi. Corpus Linguistics: Investigating Language Structure and Use. Cambridge: Cambridge University Press, 1998.

Cataldi, Mario, Di Caro, Luigi \& Schifanella, Claudio. "Emerging topic detection on Twitter based on temporal and social terms evaluation", Tenth International Workshop on Multimedia Data Mining, Washington, DC, 2010.

Chilton, Paul A. \& Schäffner, Christina. Politics as Text and Talk. Analytic Approaches to Political Discourse. Amsterdam and Philadelphia: Benjamins, 2002.

Denton, RobertE. 'The Rhetorical Functions of Slogans: Classifications and Characteristics', Communication Quarterly 28/2 (1980): 10-18.

Garlick, Elsa \& Faride, Tamara. "Latent content analysis: staff considerations on family, technical and professional work at Valparaíso's Teleton Institute", Rehabil. integral (Impr.) 6/2 (2011):72-78.

Hernando Cuadrado, Luis Alberto. "Análisis semiótico del mensaje publicitario". En José Angel Fernández Roca, Carlos Juan Gómez Blanco, José María Paz Gago (Eds), Semiótica y modernidad: actas del $V$ Congreso Internacional de la Asociación Española de Semiótica. Vol. 2, (1994): 513-524.

Hunston, Susan. "Semantic prosody revisited", International Journal of Corpus Linguistics, 12/2 (2007): 249-268. 
Ivanova, Anna. "Barack Obama's Presidential Governing on the Internet: Web 2.0 and the Pervasiveness of Political Language”. Scholar's Press: Saarbrücken, 2013. ISBN: 978-3-639-70274-3.

- "Political language in 140 symbols: Twitter use by Barack Obama and Dmitry Medvedev”, III Congreso Internacional de Lingüística de Corpus, Valencia, Spain, 2011.

Jiménez Peńuela, John. "Teletones en Chile y Colombia: De la discapacidad como caridad, y la caridad como negocio", Observatorio de la Economía Latinoamericana 161 (2012). Disponible en: http://www.eumed.net/cursecon/ecolat/co/

Leech, Geoffrey N. English in Advertising. London: Longman, 1966.

Louw, Bill. "Irony in the text or insincerity in the writer: The diagnostic potential of semantic prosody". In Mona Baker, Gill Francis \& Elena Tognini-Bonelli (Eds.), Text and Technology: In Honour of John Sinclair. Amsterdam: John Benjamins, (1993): 157-176.

Louw, Bill \& Chateau, Carmela. "Semantic prosody for the 21st Century: Are prosodies smoothed in academic contexts? A contextual prosodic theoretical perspective, Proceedings of JADT 2010": 10th International Conference on Statistical Analysis of Textual Data, (2010): 755-764.

Lu, Xing. "An ideological/cultural analysis of Political Slogans in Communist China", Discourse Society 10/4 (1999): 487-508.

Mauntner, Gerlinde. "Corpora and Critical Discourse Analysis". In Paul Baker (Ed.), Contemporary Corpus Linguistics. New York: Continuum, (2009): 32- 46.

Meyer, Charles F. English Corpus Linguistics: An Introduction. Cambridge: Cambridge University Press, 2002.

McCarthy, Michael \& Carter, Ronald. Language as Discourse: Perspectives for Language Teaching. London and New York: Longman, 1994.

McEnery, Tony, Xiao, Richard \& Tono, Yukio. Corpus-based language studies: an advanced resource book. London: Routledge, 2006.

Ortega R., Eugenio (Coord.). PNUD: Desarollo humano en Chile 2002. Santiago: LOM Ediciones, 2004.

Scott, Mike. WordSmith Tools (Version 5.0). Liverpool: Lexical Analysis Software, 2008.

Sinclair, John. Corpus, concordance, collocation. Oxford: Oxford University Press, 1991. 
Solís Fresia; Rotter Karin y Araya, Claudina. "Results evaluation in a cohort of cerebral palsy children attending the Preschoolers Functional Development National Program: Teleton Chile 2007-2009”, Rehabil. integral (Impr.) 5/2(2010): 83-94.

Stubbs, Michael. "Two Quantitative Methods of Studying Phraseology in English”, International Journal of Corpus Linguistics 7/2 (2002): 215-244.

Urdang, Laurence \& Robbins, Ceila. (Eds.). Slogans. Detroit: Gale Research Company, 1984.

Wallis, Sean \& Nelson, Gerald. "Knowledge Discovery in Grammatically Analysed Corpora", Data Mining and Knowledge Discovery 5(2001): 305-335.

Zangrandi, Marcos. "Eslóganes televisivos: Emergentes tautistas", Cuadernos del Centro de Estudios en Diseño y Comunicación 23(2007): 73-79.

Zhou, Yuyi. Longman Dictionary of Contemporary English. $4^{\mathrm{a}} \mathrm{ed}$. Beijing: Foreign Language Teaching and Research Press, 2004. 